International Journal of Social Sciences and Humanities
Available online at http://sciencescholar.us/journal/index.php/ijssh
Vol. 3 No. 1, April 2019, pages: $179 \sim 185$
e-ISSN: 2550-7001, p-ISSN: $2550-701 \mathrm{X}$
https://doi.org/10.29332/ijssh.v3n1.279

\title{
Learning Writing Description Paragraph Based on Mind Mapping
}

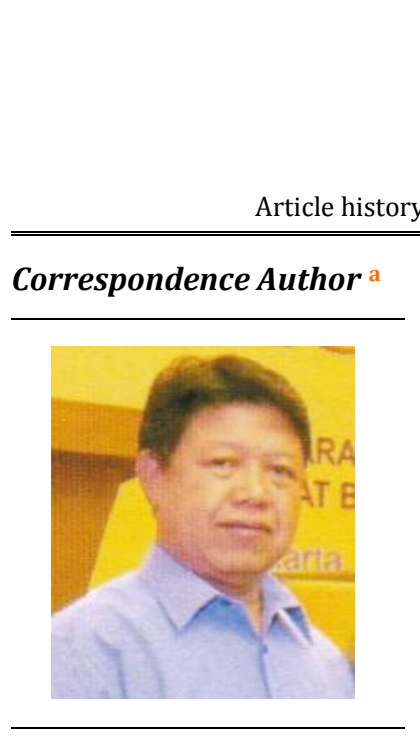

descriptive;

mapping;

mind;

paragraph;

performance;

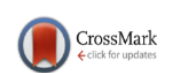

\section{Ida Bagus Putrayasa ${ }^{a}$}

Article history: Received 9 August 2018, Accepted: 31 December 2018, Published: 26 April 2019

Keywords

\begin{abstract}
This study was aimed to describe (1) instruction in writing a descriptive paragraph using mind mapping model to the seventh-grade students of SMP Negeri 2 Singaraja and (2) the ability of the seventh-grade students of SMP Negeri 2 Singaraja in writing a descriptive paragraph using mind mapping. This study used descriptive qualitative design. The subjects of this study were teachers and the seventh-grade students of SMP Negeri 2 Singaraja. The object was descriptive paragraph instruction using mind mapping. This study used an observation method and test to collect the data. The data gathered were analyzed using qualitative descriptive and quantitative descriptive analysis methods. The results showed that (1) the implementation of the instruction in writing a descriptive paragraph using mind mapping model by the teachers has closely followed the existing theory. (2) the ability of the seventh-grade students of SMP Negeri 2 Singaraja in writing a descriptive paragraph using mind mapping fell into good category. The score obtained was 76.41. Although the score obtained has fallen into category good, it seems that the teachers' performance needs to be improved by giving more intensive practices, both in writing mind mapping and in developing it into a paragraph to produce a maximum result.
\end{abstract}

e-ISSN: 2550-7001, p-ISSN: 2550-701X ๑ Copyright 2019. The Author. SS Journals Published by Universidad Técnica de Manabí. This is an open-access article under the CC BY-SA 4.0 license (https://creativecommons.org/licenses/by-sa/4.0/) All rights reserved.

\section{Contents}

Abstract.

1. Introduction .

2. Materials and Methods...... 180

3. Results and Discussions 181

4. Conclusion 183 
Acknowledgements................................................................................................................................................. 183

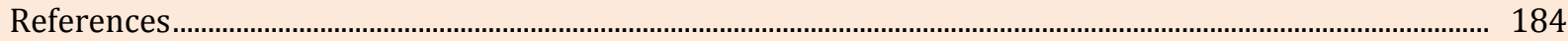

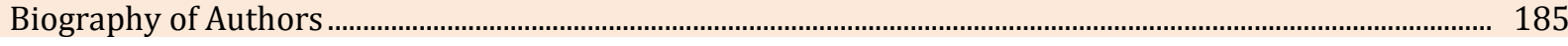

\section{Introduction}

The end goal of Indonesian language learning is focused on the language skills aspect. One aspect of such language skills is writing skill. This writing skill needs to be taught from the beginning because it is very beneficial for improving intellectual, as Mets especially the thinking skills of learners (Al-Jarf, 2009; Hector, 2011). DePorter (2005), suggests that writing is the activity of the entire brain, both right and left hemispheres (logic) to maximize their functions.

Writing skills is the ability to express opinions and feelings to others through written language (Wai Ling, 2004; Shahriar et al., 2011). Skill measurements can be performed during a learning process that is deliberately done for that purpose. One of the instruments to measure writing skill during the learning process. Gie (2003), says that writing consists of a whole series of activities to express ideas and pass them through written language to the reader's community. Writing activity is an activity to actualize the potential that exists within a person to make progress in his or her life (Zaqeus in Satrya, 2011).

Based on preliminary observations in class VII of SMP Negeri 2 Singaraja, the researcher found that students still had difficulty in writing the descriptive paragraph. The problems students faced in writing the description paragraphs are the inability of students to find what they want to write, what the topic was and how to begin. In addition, students were less able to plan ideas or ideas regularly and logically-systematically. This is evident from the student's writing that looks coherence. Students also have not been able to use good and appropriate Indonesian language. It is clear that students were less precise in the use of words and sentences in their writing and were less precise in applying written spellings (Al-Jarf, 2011).

Although it is well known that writing is very useful for improving the intellectual aspect (thinking skills), this writing activity is very difficult to do by the students (learners). This difficulty is caused by several things. First, theoretically, the teacher in teaching writing begins with explanations of technical terms. These theoretical explanations do not provide an adequate understanding of writing. Second, methodologically, the way the teacher gives the writing topic. There are three ways in which the lecturer provides the oral topic: (1) establishing a topic for all learners to write down, (2) specifying several topics for one to be developed by the learner, and (3) freeing the learner to choose his or her own topic. The first and second ways have a risk because do not have sufficient knowledge to develop the topics provided. The third way seems to give the learner the opportunity to develop his or her skill. However, there are concerns that they are given the freedom to develop the topics they are most capable of. The ideas they develop into writings are unfocused, uncontrolled, 'wild' because their minds are not directed to create logical-systematic ideas. To anticipate such concerns, one of the models offered in this study is the mind mapping model (https://litemind.com/whats-ismind-mapping/, (2013); Mashable.com, 2013); Budd (2004). With this model, once it has been observed, students can map their thoughts or idea logically and systematically, and develop them into coherent writing (Hiranabe, 2017). The problems are: (1) what did the learning to write a descriptive paragraph with mind mapping model on the seventh-grade students of SMP Negeri 2 Singaraja look like? (2) To what extent were of the seventh-grade students of SMP Negeri 2 Singaraja able to write a descriptive paragraph with mind mapping?

\section{Materials and Methods}

This research used a descriptive qualitative and quantitative design. The subjects in this study were teachers and students of class VII SMP Negeri 2 Singaraja in learning descriptive paragraph with mind mapping model. This study used two kinds of methods to collect data, namely the methods of observation and test. The data collected were analyzed by qualitative descriptive and descriptive quantitative analysis methods. The guidelines used to assess the ability to write a student descriptive paragraph were as follows: (a) 85-100 (Very good), (b) 70-84 (Good), (c) 55-69 (Enough), (d) 40-54 (Less), and (e) 25-39 (Very less). 


\section{Results and Discussions}

This descriptive research was conducted on the seventh-grade students of SMP Negeri 2 Singaraja. Prior to the learning of writing with mind mapping, students were asked to write descriptive paragraphs with free themes defined by the students themselves. This step was done to get initial information about students' writing skills. The initial results of the writing skills of the seventh-grade students of SMP Negeri 2 Singaraja can be seen in Table 1 below.

Table 1

Early ability scores of grade VII students SMP Negeri 2 Singaraja in writing description paragraph

\begin{tabular}{|c|c|c|c|}
\hline No. & Student Code & Score & Predicate \\
\hline 1. & $\mathrm{~S}-1$ & 60 & Enough \\
\hline 2. & $\mathrm{~S}-2$ & 50 & Less \\
\hline 3. & $\mathrm{~S}-3$ & 66 & Enough \\
\hline 4. & S-4 & 65 & Enough \\
\hline 5. & S-5 & 59 & Enough \\
\hline 6. & S-6 & 72 & Good \\
\hline 7. & S-7 & 67 & Enough \\
\hline 8. & S-8 & 55 & Enough \\
\hline 9. & S-9 & 64 & Enough \\
\hline 10. & S-10 & 60 & Enough \\
\hline 11. & S-11 & 63 & Enough \\
\hline 12. & S-12 & 50 & Less \\
\hline 13. & S-13 & 70 & Good \\
\hline 14. & S-14 & 61 & Enough \\
\hline 15 & S-15 & 59 & Enough \\
\hline 16. & S-16 & 58 & Enough \\
\hline 17. & S-17 & 65 & Enough \\
\hline 18. & $\mathrm{~S}-18$ & 74 & Good \\
\hline 19. & S-19 & 66 & Enough \\
\hline 20. & S-20 & 61 & Enough \\
\hline 21. & S-21 & 51 & Less \\
\hline \multirow[t]{3}{*}{22.} & S-22 & 58 & Enough \\
\hline & Total & 1.354 & \\
\hline & Average & 61,55 & Enough \\
\hline
\end{tabular}

Based on Table 1 above, it can be said that the average ability of students in writing paragraph description with mind mapping was 61,55 . This is insufficient category. The average score indicates that the students' writing ability is still far from the minimal mastery of learning, which is 70 . It also means that students' writing skills need to be improved by using a more innovative model of learning so that students' abilities can also increase toward a complete mastery of learning level.

One of the models that have been recommended to teachers who teach in the classroom is the mind mapping model. Before the learning process is done, the students are introduced to the concept of mind mapping learning, the steps of learning-teaching writing with mind mapping, and the application of mind mapping in learning to write a description in the classroom (D'Antoni \& Pinto Zipp, 2005; Mento et al., 1999).

Learning to write a descriptive paragraph with a mind mapping model by the teacher followed the learning steps that had been designed. The implementation of the lesson begun with prior knowledge related to teaching-learning to write a descriptive paragraph. Teachers informed the basic competencies and learning objectives to be achieved. One of the basic competencies was 'writing the observation result in the form of a

Putrayasa, I. B. (2019). Learning writing description paragraph based on mind mapping. International Journal of Social Sciences and Humanities, 3(1), 179-185. https://doi.org/10.29332/ijssh.v3n1.279 
descriptive paragraph. In the meantime, the targets to be achieved in the lesson were : (a) to list the topics that caould be developed into the descriptive paragraph, (b) to develop the description framework, (c) to develop the framework that has been compiled into paragraphs of description, and (d) to editing descriptive paragraphs written by other students. Associated with the use of mind mapping in writing descriptive paragraphs, the teacher just adjusted it to the purpose of learning that has been determined.

Entering the core activities, the teacher started by explaining the concept of writing descriptive paragraphs, mind mapping, mind mapping steps, and teaching-learning steps to writing a descriptive paragraph with mind mapping. In addition to the subject matter described, the teacher also explained components that support the creation of good writing, such as sentence and spelling. The teacher also provided an example of mind mapping and how to develop it into a paragraph so that students' understanding of writing a descriptive paragraph with mind mapping could improve. Although they had been given the example of mind mapping and how to develop it into a paragraph, there were some students who were still experiencing obstacles in practice. The results of students' ability in writing the description paragraph with mind mapping can be seen in the following description. The ability of students to write a descriptive paragraph with mind mapping can be seen in Table 2 below.

Table 2

Student ability score in writing description paragraph with mind mapping

\begin{tabular}{llll}
\hline No. & Student Code & Score & Predicate \\
\hline 1. & S-1 & 72 & Good \\
\hline 2. & S-2 & 70 & Good \\
\hline 3. & S-3 & 80 & Good \\
\hline 4. & S-4 & 77 & Good \\
\hline 5. & S-5 & 73 & Good \\
\hline 6. & S-6 & 86 & Very Good \\
\hline 7. & S-7 & 85 & Very Good \\
\hline 8. & S-8 & 70 & Good \\
\hline 9. & S-9 & 85 & Very Good \\
\hline 10. & S-10 & 77 & Good \\
\hline 11. & S-11 & 82 & Good \\
\hline 12. & S-12 & 70 & Good \\
\hline 13. & S-13 & 85 & Good \\
\hline 14. & S-14 & 74 & Good \\
\hline 15 & S-15 & 70 & Good \\
\hline 16. & S-16 & 70 & Good \\
\hline 17. & S-17 & 81 & Good \\
\hline 18. & S-18 & 89 & Very Good \\
\hline 19. & S-19 & 81 & Good \\
\hline 20. & S-20 & 61 & Enough \\
\hline 21. & S-21 & 68 & Enough \\
\hline 22. & S-22 & 75 & Good \\
\hline & Total & 1.681 & \\
\hline & Mean & 76,41 & Good \\
\hline & & & \\
\hline
\end{tabular}

Based on Table 2 above, it can be explained that the students' ability to write descriptive paragraphs with mind mapping, in general, can be said to be quite good with an average score of 76,41 . If detailed again the general exposure of the acquisition of the ability to write paragraph descriptions of class VII students of SMP Negeri 2 Singaraja is shown as follows: (a) Very good: 4 (18\%), (b) Good: 16 (73\%), (c) Enough: 2 (9\%), (d) Less: $0(0 \%)$, and (e) Very less: $0(0 \%)$.

Based on the data in Table 2 above, it can be explained that from 22 students of class VII SMP Negeri 2 Singaraja who followed the learning writing paragraph description with mind mapping: 4 students (18\%) got 
very good scores; 16 students (73\%) got good scores; 2 students (9\%) got enough scores. In the meantime, no students $(0 \%)$ received less and very less. Based on the percentage, the classical learning writing paragraph description with mind mapping is said to result because $91 \%$ of students score 70 up or with good and very good value.

The data shows that there is a change in the ability to write paragraph descriptions of class VII students of SMP Negeri 2 Singaraja from before and after the learning with mind mapping. The mean score before the mind mapping model was implemented in learning to write a descriptive paragraph was 61,55 and after the implementation of model mean score became 76,41. This means that there was an increase in the score of 14.86.

In general, students were careful enough to make mind mapping because the ideas they put into mind mapping represented what they really mean. Students had focused on the topics developed in mind mapping so that they were directed in the development of the idea (Zampetakis, 2007; Wikramisinghe, 2007). This happened because the students often got training to make mind mapping as one way in developing their ideas. Training to develop ideas with mind mappings should also be done correctly using a variety of colors so that the results obtained in writing descriptive paragraph could be maximal. This was consistent with what Silberman (1996) \& O'Gara (2017) said. They said that in making a simple mind mapping learners should use color, images, or symbols. Explaining how colors, images, or symbols in our mind map (teacher) increases the whole work of the mind. Learners are instructed to insert simple examples from their everyday life that they can make their mind maps.

Furthermore, Silberman (1996), says that it is better to put paper, markers, and other summaries that we think will help the learner create a bright and vibrant mind map. Assign the learner to create a mind map. Suggest that learners start their maps by creating image centers, depicting their main topics or ideas. Encourage them to split the whole into smaller elements and illustrate these elements around the message (using color and graphics). Order them to reveal each idea using the image, with a few possible words. After that, they can detail it in their minds. In parallel to this, Hernowo (2003), says that prior to writing, the central idea should be created as a theme which is subsequently broken down into subthemes logically and systematically.

The next finding that is related to the writing device is the incompleteness of the sentence, especially the core elements of the sentence contained in the student's writing. In general, the sentences in the descriptive paragraph are incomplete, there is only the subject or there is the only predicate. This happened because the students do not understand what elements should be included in the sentence. The students should have been given the understanding by the teacher about the minimal elements that must exist in the sentence, namely the subject and predicate elements. This is in accordance with what is stated by Putrayasa $(2012,2014)$ \& Nordquist (2016), who show that in a sentence, the minimal element that must exist is the core element of the sentence, the subject, and the predicate. These elements give a complete sense in the sentence. These elements can also be developed with objects, complement, or adverbial (Osborne, 2012).

\section{Conclusion}

Learning to write a descriptive paragraph with the mind mapping model by the teacher is in accordance with the existing theory. Teachers need to provide enough exercises in mind mapping and train students to develop ideas into coherent writing. The ability of grade VII students of SMP Negeri 2 Singaraja in writing the description paragraph was good. The mean score obtained was 76,41 . Although the score obtained did not reach the good category, the performance of students should be improved again by providing more intensive exercises, both in making the mind mapping and developing it into paragraphs, to achieve maximum results.

\section{Acknowledgments}

The author would like to acknowledge the editor and reviewer of IJSSH for their valuable time, support, and advice in completing the current research.

Putrayasa, I. B. (2019). Learning writing description paragraph based on mind mapping. International Journal of Social Sciences and Humanities, 3(1), 179-185. https://doi.org/10.29332/ijssh.v3n1.279 


\section{References}

Al-Jarf, R. (2009). Enhancing freshman students'writing skills with a mind-mapping software. In Conference proceedings of» eLearning and Software for Education "(eLSE) (No. 01, pp. 375-382). " Carol I" National Defence University Publishing House. https://www.ceeol.com/search/article-detail?id=38737

Al-Jarf, R. (2011). Teaching spelling skills with a mind-mapping software. Asian EFL Journal Professional Teaching Articles, 53, 4-16. http://70.40.196.162/PTA/Volume-53-raj.pdf

Budd, J. W. (2004). Mind maps as classroom exercises. The Journal of Economic Education, 35(1), 35-46. https://doi.org/10.3200/JECE.35.1.35-46

Butler, T. J., \& Pinto-Zipp, G. (2005). Students' learning styles and their preferences for online instructional methods. Journal of Educational Technology Systems, 34(2), 199-221. https://doi.org/10.2190\%2F8UD2BHFU-4PXV-7ALW

Chan, W. L. (2004). The effectiveness of using mind mapping skills in enhancing secondary one and secondary four students' writing in a CMI school. HKU Theses Online (HKUTO).

D'Antoni, A. V., \& Zipp, G. P. (2006). Applications of the mind map learning technique in chiropractic education: A pilot study and literature review. Journal of Chiropractic Humanities, 13, 2-11. https://doi.org/10.1016/S1556-3499(13)60153-9

Deporter, B., \& Hernacki, M. (2005). Quantum Learning (edisi terjemah oleh Alwiyah Abdurrahman). Bandung: PT. Mizan Pustaka.

Gie, T.L. (2003). Skillfully Compose. Yogyakarta: Andi Offset

Hernowo. (2003). Quantum Writing. Bandung: Main Media Mizan

Hiranabe, K. (2008). Exploring User Requirements through Mind mapping. https://origin2.cdn.componentsource.com/sites/default/files/resources/changevision/535931/exploringuserrequirementsthroughmindmapping.pdf

Imran, M., \& Shahriar, R. Md. Jahidur, Rahman.(2011). Mind map for academic writing: a tool to facilitate university level student. International Journal of Educational Science and Research, 1(1), 21-30.

Mento, A. J., Martinelli, P., \& Jones, R. M. (1999). Mind mapping in executive education: applications and outcomes. Journal of Management Bevelopment, 18(4), 390-416. https://doi.org/10.1108/02621719910265577

Nordquist, R. (2016). Grammar basics: sentences parts and sentences structure. http://grammar.about.com/od/rs/fl/sentence-structure.htm

O'Gara, J. (2017). Organize throughts with List of the 10 Best Mind-Mapping Tools

Osborne, T., Putnam, M., \& Groß, T. (2012). Catenae: Introducing a novel unit of syntactic analysis. Syntax, 15(4), 354-396. https://doi.org/10.1111/j.1467-9612.2012.00172.x

Putrayasa, I. B., Ramendra, D. P., \& Aryana, I. B. P. M. (2018, August). The Types of Sentence in the Essays of Grade VI Elementary School Students in Bali Province: A Syntactic Study. In Fourth Prasasti International Seminar on Linguistics (Prasasti 2018). Atlantis Press.

Putrayasa, I. B., Ramendra, D. P., \& Aryana, I. B. P. M. An Analysis of Sentences' Unity of Students' Compositions at Grade VI of Elementary Schools in Bali Province.

Putrayasa, I. B., Ramendra, D. P., \& Aryana, P. M. (2018, December). The Analysis of Sentences Structure of Students Compositions at Grade VI of Elementary Schools in Bali Province. In International Conference on Language, Literature, and Education (ICLLE 2018). Atlantis Press.

Santiago, H. C. (2011). Visual Mapping to Enhance Learning and Critical Thinking Skills. Optometric Education, 36(3). https://pdfs.semanticscholar.org/4ffe/4663ad575c0d194ea2de62fd2ad366a13983.pdf

Satrya, D.G. (2011). Creative Writing. Jakarta: PT. Achievement Ptakaraya

Silberman, M. (1996). Active Learning: 101 Strategies To Teach Any Subject. Prentice-Hall, PO Box 11071, Des Moines, IA 50336-1071.

Wickramasinghe, A., Widanapathirana, N., Kuruppu, O., Liyanage, I., \& Karunathilake, I. M. K. (2011). Effectiveness of mind maps as a learning tool for medical students. South East Asian Journal of Medical Education.

Zampetakis, L. A., Tsironis, L., \& Moustakis, V. (2007). Creativity development in engineering education: The case of mind mapping. Journal of Management Development, 26(4), 370-380. https://doi.org/10.1108/02621710710740110

Zaqeus, E. (2008). Resep cespleng menulis buku bestseller. Fivestar. 


\section{Biography of Author}

\begin{tabular}{|l|l|l||}
\hline \hline & $\begin{array}{l}\text { Ida Bagus Putrayasa is a professor at the Ganesha University of Education, Bali- } \\
\text { Indonesia. He was born in Desa Banjar, Buleleng Regency on February 10 }\end{array}$ \\
& 1960. He graduated his primary school in Desa Banjar (1972), junior high school \\
in Desa Banjar (1975), SPG in Singaraja (1979), S-1 in Singaraja (1984 ), S-2 in \\
Bandung Teachers' Training College (1998), and S-3 at UPI Bandung (2001). He \\
was in 2004 established as a professor in linguistics field. He lived at Jalan \\
Laksamana Barat, Gang Sandat No.7, Desa Pemaron, Singaraja-Bali. Ph. \\
081338570420.Email: ibputra@gmail.com
\end{tabular}

Putrayasa, I. B. (2019). Learning writing description paragraph based on mind mapping. International Journal of 